\title{
SURGA YANG TAK DIRINDUKAN: WACANA POLIGAMI DALAM FILM ISLAMI
}

\author{
Oleh: Ana Zahida \\ Dosen Univeristas Islam Negeri Sunan Kalijaga Yogyakarta \\ Email: anzahida@gmail.com
}

\begin{abstract}
One of the interesting aspects in the widely developing Indonesian film industry is how Islamic film genre brings about some socio cultural issues through the lense of Islamic perspective. Hence, this article primarily aims to analyze the discourse of polygamy in one of the Islamic popular films Surga Yang Tak Dirindukan 1 and 2 (The Unwanted Heaven). The film was analyzed with semiotic methodology which treates film as linguistic text so as to ease the process of structural principles underlying the film. By and large, the structural analysis of the film pinpoints that the film represents the ideal construction of Muslim men and women, the ideal relation of husband and wife through Islamic perspective, and the discourse of polygamy as the solution for many social problems. This ideal construction of polygamy discourse is primarily based on the textualist interpretation of Quranic verses on polygamy. All in all, the ideal representation of Islamic polygamy discourse does not allow a room for the complications mostly taking place in polygamous marriage.
\end{abstract}

Keywords: polygamy, construction, semiotics, Islamic film

\begin{abstract}
Abstrak
Salah satu perkembangan industri film yang cukup menarik di Indonesia adalah bagaimana genre film islami mengangkat berbagai isu sosial budaya melalui perspektif islami. Oleh karena itu, artikel ini ditulis dengan tujuan menganalisis wacana poligami dalam salah satu film islami populer Surga Yang Tak Dirindukan 1 dan 2. Teknik analisis film dilakukan dengan metodologi semiotika yang memperlakukan film sebagaimana teks bahasa sehingga memudahkan penulis untuk menganalisis prinsip struktural yang mendasari film. Analisis struktural pada film tersebut menunjukkan bahwa secara umum film merepresentasikan konstruksi laki-laki dan perempuan muslim ideal, relasi ideal antara suami dan istri dalam perspektif Islam, dan juga wacana poligami yang bisa menjadi solusi atas berbagai permasalahan sosial. Konstruksi ideal wacana poligami tersebut didasarkan atas interpretasi para tekstualis atas ayat-ayat Quran tentang poligami. Hanya saja, representasi ideal wacana poligami islami tersebut tidak memberikan ruang atas berbagai komplikasi yang kerap kali terjadi pada pernikahan poligami.
\end{abstract}

Kata kunci: poligami, konstruksi, semiotika, film islami 


\section{Pendahuluan}

Tulisan ini akan membahas tentang wacana poligami yang dikonstruksi dalam film Surga Yang Tak Dirindukan dan sekuelnya Surga Yang Tak Dirindukan 2, film islami populer yang belum lama diproduksi di tahun 2015 dan 2016. Dua film populer ini dengan lika-liku cerita antar tokohnya dengan jelas menunjukkan posisi pro poligami dengan mengetengahkan konstruksi poligami yang Islami dan mampu memberikan solusi atas berbagai permasalahan.

Hal ini terutama dapat dilihat melalui dua karakter perempuan yang menjadi titik permasalahan film ini dan cara mereka untuk menegosiasi hubungan poligami dengan karakter pria. Negosiasi ini terkait erat dengan alasan mereka untuk menolak hingga pada akhirnya menerima poligami dan keputusan mereka untuk tetap mempertahankan pernikahan poligami yang tidak terlepas dari pergulatan batin dan relasi kuasa antara ketiga tokoh utama dalam film ini. Selain itu, dalam artikel ini, akan dibahas pula konstruksi poligami Islami yang direpresentasikan dalam film ini dan korelasinya dengan aspek sosial, budaya dan ekonomi.

Metodologi yang digunakan dalam penelitian ini adalah semiotika yang memperlakukan film sebagai sebuah teks yang mempunyai karakter seperti halnya bahasa sehingga memudahkan proses analisis prinsip struktural yang mendasari film tersebut.

\section{Pembahasan}

\section{Rasionalisasi Poligami dalam film Islami}

Wacana tentang poligami selalu menjadi isu kompleks dan kontroversial dari waktu ke waktu. Hal ini tidak terlepas karena adanya relasi kuasa antara pria dan wanita yang terlibat dalam praktik pernikahan poligami. Dampak poligami yang masif dan terkait erat dengan masalah warisan dan kepemilikan harta benda kerap kali juga menjadi sumber permasalahan yang cukup pelik. Hanya saja artikel ini hanya akan terfokus pada representasi wacana dan konstruksi poligami dalam film ini. Hal ini karena terdapat keterkaitan erat antara film Islami dengan wacana gender karena pemaknaan terhadap gender seringkali direpresentasikan dalam film. Hal ini didasarkan atas pemikiran Judith Butler tentang Performativitas Gender yang menekankan pemaknaan gender pada apa yang dilakukan seseorang dan pada apa yang dikutipnya (gender citation). ${ }^{1}$ 
Rezim Orde Baru yang mengukuhkan wacana pernikahan monogami dan membatasi jumlah anak dalam program Keluarga Berencana dengan dua anak cukup, telah mengerdilkan perkembangan dunia perfilman Indonesia. Sebagaimana dinyatakan oleh Krishna Sen bahwa 'dunia perfilman pada rezim Orde Baru Suharto menutup akses untuk bereksperimen.'2 Akibatnya, di bawah kekuasaan rezim Suharto industri perfilman Indonesia cenderung tidak berkembang karena ketatnya sensor dan monopoli distribusi. Hal ini menurut Sen, juga berpengaruh pada representasi gender dan seksualitas dalam film. Pada masa Orde Baru 'mayoritas genre film Indonesia didominasi oleh cerita tentang pria dan 'lingkup tindakan pria' dengan karakter perempuan yang subordinat dan hanya menjadi pelengkap cerita tokoh utama pria. $^{3}$

Namun demikian, sejak tahun 1990-an hingga sekarang industri hiburan tanah air mulai menunjukkan perkembangan berbagai macam bentuk media Islam dan budaya populer yang merefleksikan pergeseran selera dan kebutuhan pasar yang berbeda ini. ${ }^{4}$ Hal ini ditandai dengan munculnya produk budaya berlabel Islami mulai dari musik pop dan rok Islami, majalah wanita islami, komik islami, sinetron islami, hingga genre film Islami. Untuk dapat menarik minat audiens Muslim yang taat dan juga para remaja di tengah gelombang popularitas film barat, genre film Islami biasanya dipenuhi dengan representasi Muslim perempuan dan laki-laki ideal. ${ }^{5}$

Meskipun tidak melulu berbicara tentang masalah agama, Surga yang Tak Dirindukan dapat digolongkan ke dalam kategori genre film islami yang menurut Izharuddin dapat ditandai dengan adanya kutipan ayat-ayat Al Quran dalam dialog dan penggunaan berbagai simbol Islami seperti Masjid, jilbab, ataupun pesantren yang memiliki signfikansi tersendiri dalam jalinan cerita. ${ }^{6}$ Hanya, saja film ini bukan film islami pertama yang mengangkat isu tentang poligami karena sebelumnya telah ada Ayat-Ayat Cinta (2008) yang merupakan salah satu pelopor genre film islami bertema poligami. ${ }^{7}$

Selain film islami bertema poligami, publik Indonesia telah lebih dulu akrab dengan film umum bertema poligami yang diterima dengan kontroversial, Berbagi Suami (2006). Film yang disutradarai oleh sutradara perempuan Nia Dinata ini merepresentasikan praktik poligami dalam perspektif kritis. Melalui penggalan cerita tiga orang perempuan yang tidak saling kenal satu sama lain, Dinata mencoba mengonstruksikan berbagai bentuk praktik pernikahan poligami dalam setting ranah sosial, budaya dan representasi politik yang berbeda dengan merujuk pada praktik sosial poligami yang ada di Indonesia. ${ }^{8}$ Poligami dalam perspektif Dinata adalah suatu praktik patriarkis phallosentris yang semata timbul dari 
keinginan untuk memuaskan hasrat kelelakian. Namun akibatnya sungguh kompleks bagi para istri yang dipoligami dan juga anak-anak mereka. Film secara gamblang merepresentasikan perempuan sebagai pihak yang tersubjeksi terlepas bagaimanapun status sosial dan latar belakang pendidikan yang mereka miliki. Mereka seolah tidak punya ruang untuk bernegosiasi. Yang tersedia bagi perempuan dalam Berbagi Suami hanya dua pilihan, menerima atau menolak sama sekali.

Berbeda dengan Berbagi Suami yang notabene merupakan film bergenre fiksi populer, film Islami merepresentasikan poligami dalam perspektif yang dipenuhi dengan idealitas agama. Sebagai film yang dibuat dengan tujuan media dakwah, film Islami bertema poligami cenderung merepresentasikan poligami sebagai bentuk solusi atas berbagai permasalahan. Hal ini sebagaimana terlihat dalam konstruksi film islami bertema poligami pertama, Ayat-Ayat Cinta yang menampilkan seorang mahasiswa Indonesia yang belajar di Mesir yang 'terpaksa' menikahi gadis Mesir non Muslim demi menyelamatkan akidahnya dan membimbingnya ke jalan Islam. Konstruksi yang serupa juga terdapat dalam film Surga yang Tak Dirindukan 1 dan sekuelnya Surga yang Tak Dirindukan 2.

Diangkat dari novel karya novelis Islami Asma Nadia, Surga yang Tak Dirindukan 1 dan 2 adalah sebuah film islami yang cukup signifikan dan memiliki tempat tersendiri di hati masyarakat Indonesia. Hal ini terbukti dari jumlah penonton film pertama yang menembus angka hingga 2 juta penonton lebih sehingga menjadikannya film terlaris IBOMA di tahun 2016. ${ }^{9}$ Sekuelnya juga disambut dengan tidak kalah meriah oleh penonton di tahun 2017.

Disutradari oleh Agus Kuntz film pertama mengangkat isu sensitif poligami melalui jalinan kisah kasih keluarga Arini (Laudya Cynthia Bella) dan Prasetya (Fedi Nuril) yang sangat ideal dan Islami. Arini merepresentasikan figur perempuan Jawa modern yang tidak saja cantik dan lembut, namun juga cerdas, berpendidikan tinggi, independen secara finansial (karirnya di dunia penulisan novel sedang menanjak), dan taat beragama (ditandai dengan gaya berpakaian yang selalu menutup aurat, praktik ibadah yang konsisten, dan selalu merujuk pada Al Quran dalam mengambil segala keputusan). Sama halnya dengan Arini, Pras juga digambarkan sebagai seorang pria Jawa yang sempurna karena ketampanan, budinya yang halus, pengetahuannya dalam agama, dan juga pekerjaannya yang mapan sebagai arsitek ternama. Kebahagiaan pasangan muda ini semakin bertambah dengan kelahiran putri cantik mereka Nadia (Sandrina Michelle) di tengah keluarga. 
Berbagai atribut sosial yang melekat pada Arini dan Pras merepresentasikan konstruksi idealitas keluarga Islam yang ingin dibangun dalam film ini. Bahwa keluarga Islam yang ideal selalu didasarkan pada ekualitas nilai yang dimiliki oleh pasangan atau yang dalam istilah Islam disebut sebagai $k u f u$ '. Kebahagiaan keluarga juga terletak pada hadirnya seorang anak tengah keluarga dan pengabdian seorang ibu yang di tengah kesibukannya di ruang publik masih dapat menyelesaikan tugas rumah tangga dengan baik. Keluarga bahagia Arini dan Pras dalam film Islami populer ini merepresentasikan idealitas keluarga muslim kelas menengah modern yang tidak hanya mapan secara finansial tetapi juga mapan dalam hal pengetahuan agama.

Konstruksi idealitas keluarga muslim kelas menengah dalam film terletak pada kemampuan untuk menyeimbangkan antara kepentingan dunia dan akhirat. Muslim kelas menengah modern direpresentasikan sebagai individu yang produktif dan kreatif, berpendidikan tinggi, dan memiliki gaya hidup yang cenderung konsumtif sebagaimana terlihat dari scene tentang belanja di mall, melakukan pertemuan di kafe, dll. Sedangkan, kesalehan agama mereka terletak pada ritual keagamaan yang mereka laksanakan secara rutin - wudhu, mengaji, shalat - dan juga atribut agama yang melekat pada tubuh mereka (jilbab, mukenah, peci).

Terlepas dari scene yang menunjukkan kepedulian sosial Arini dan Pras pada mereka yang kurang mampu, titik berat film ini lebih pada lika-liku masalah personal rumah tangga Arini dan Pras. Benih permasalahan timbul bukan karena karakter pribadi Arini dan Pras yang diceritakan sudah memenuhi idealitas Islami, melainkan dari munculnya perempuan lain, pihak asing yang membutuhkan pertolongan dan belas kasih dari pasangan ini.

Film ini dengan lancar mengisahkan bagaimana kisah poligami itu bermula dan bagaimana hal tersebut menjadi sesuatu yang tidak dapat dihindarkan oleh Pras. Takdir menjadi penentu klise pertemuan antara Pras dan Meirose (Raline Shah) dalam sebuah kecelakaan mobil yang dialami oleh Meirose. Takdir ala film pula yang membuat Pras terpaksa 'harus' menyelamatkan Meirose dengan cara menikahinya karena wanita ini sedang mengalami depresi akibat ditinggalkan oleh kekasih di hari pernikahannya. Janin berusia 7 bulan dalam kandungan Meirose menjadi alasan utama Pras untuk berpoligami.

Film dengan gamblang merasionalisasi alasan Pras untuk berpoligami. Bahwa poligami dalam kisah ini bukan timbul dari hasrat pribadi Pras. Hal ini tidak terlepas dari sifat 
welas asih Pras melihat kemalangan yang menimpa Meirose. Film menjadikan Meirose sebagai pihak yang wajib ditolong dan layak mendapatkan bimbingan dari pria yang matang pengetahuan agamanya dan mapan seperti Pras, dan hal tersebut dapat dilakukan hanya melalui pernikahan poligami.

Konstruksi yang sama terlihat jelas dalam film Ayat-Ayat Cinta yang juga diperankan oleh Fedi Nuril. Dalam film tersebut terlihat bagaimana poligami merupakan sesuatu yang tidak dapat dihindarkan. Poligami adalah perintah Tuhan yang merupakan solusi atas berbagai permasalahan. Fahri dalam film Ayat-Ayat Cinta 'terpaksa' harus menikahi Maria yang sedang sekarat dan tidak memiliki harapan hidup. Poligami dilakukan demi menyelamatkan akidah Maria yang baru masuk Islam dan juga demi membimbingnya ke jalan Islam. Karakter Fahri tidak ubahnya seperti Pras yang 'terpaksa' harus menikahi Meirose demi menyelamatkan dia dan anaknya yang yatim.

Konstruksi yang terlihat dalam dua film islami bertema poligami tersebut merepresentasikan sebuah pernyataan jelas tentang maskulinitas pria Muslim yang diharuskan mampu memberikan pertolongan kepada para wanita yang lemah. Pria muslim yang taat sebagaimana Fahri ataupun Pras direpresentasikan sebagai sang penolong, sedangkan perempuan yang berputus asa dan kurang memiliki pengetahan agama seperti halnya Maria ataupun Meirose ditampilkan sebagai pihak yang lemah dan harus ditolong. Ideologi patriarkal dalam film terlihat dari representasi sang laki-laki muslim yang dominan dan si perempuan non islami yang terdominasi. Pria muslim yang taat seolah dititahkan untuk menjadi Mesiah bagi para wanita yang membutuhkan pertolongan dan bimbingan agama.

Rasionalisasi poligami juga ditampilkan melalui permohonan para perempuan lemah tersebut. Dalam kondisi kemalangan yang tidak tertahankan, poligami seolah menjadi satusatunya jalan bagi para perempuan lemah tersebut untuk mendapatkan kebahagiaan. Diceritakan bagaimana Meirose yang telah putus asa karena tidak mampu lagi melanjutkan hidup memohon kepada Pras untuk menikahinya. Film merepresentasikan permohonan Meirose ini sebagai keniscayaan yang tidak dapat dihindarkan. Pada bagian ini terlihat jelas bagaimana poligami diposisikan sebagai sebuah perintah tuhan yang harus dilaksanakan demi mengatasi berbagai permasalahan yang sedang merundung seorang wanita lemah seperti Meirose. 
Meirose adalah representasi dari mereka yang lemah. Ia adalah sebuah perwujudan dari permasalahan sosial yang timbul dari banyaknya perempuan yang menjadi korban para lelaki yang tidak bertanggung jawab dan tidak relijius. Film memberikan satu-satunya solusi bagi para perempuan semacam ini melalui pernikahan poligami.

Perspektif poligami sebagai sebentuk perintah Tuhan untuk menyelamatkan umat manusia dari berbagai permasalahan sosial sejalan dengan pandangan fundamentalis yang menempatkan poligami sebagai bentuk sunnah dan praktik shariah. ${ }^{10}$ Kelompok fundamentalis Islam kerap kali menyitir ayat Al Quran surat Annisa ayat 3 untuk membenarkan pandangan mereka tentang poligami. "Dan jika kamu takut tidak akan dapat berlaku adil terhadap (hak-hak) perempuan yatim (bilamana kamu mengawininya), maka kawinilah wanita-wanita (lain) yang kamu senangi: dua, tiga atau empat. Kemudian jika kamu takut tidak akan dapat berlaku adil, maka (kawinilah) seorang saja, atau budak-budak yang kamu miliki. Yang demikian itu adalah lebih dekat kepada tidak berbuat aniaya. [AnNisa: 3]."

Ayat tersebut melatarbelakangi interpretasi mereka bahwa seorang pria Muslim bisa menikahi lebih dari satu perempuan yang dibatas sampai jumlah maksimal empat. Selain itu, Al Manhajj yang merupakan media Salafiyyah juga mengutip hadits Nabi yang menyatakan manfaat poligami, "Menikahlah, karena sesungguhnya orang yang paling dirahmati oleh Tuhan adalah mereka yang memiliki banyak istri." 11

Rasionalisasi poligami dalam film Surga yang Tak Dirindukan 1 dan 2 tidak terlepas dari trend poligami yang sedang terjadi di Indonesia. Berbagai publik figur dari kalangan dai kondang seperti Aa' Gym dan Arifin Ilham, politisi seperti Hamzah Haz dan Anis Matta, dan pengusaha ternama seperti Puspo Wardoyo, dikabarkan memiliki istri lebih dari satu. Bahkan Puspo Wardoyo tidak segan untuk mengkampanyekan praktik poligami kepada masyarakat melalui program 'Polygami Award' di tahun 2003. Mereka yang terpilih dalam program ini akan mendapatkan penghargaan dan juga hadiah uang.

Para pendukung praktik poligami tersebut berpandangan bahwa poligami diatur secara jelas dan terang diperbolehkan dalam Al Quran. Para kelompok pro poligami yang didukung fundamentalis ini bahkan tidak segan menyerang mereka yang menolak poligami sebagai pihak yang telah 'terkontaminasi oleh ideologi barat', ${ }^{12}$, padahal poligami sendiri dipandang sebagai praktik yang bertujuan menacapai keadilan mengingat banyaknya jumlah perempuan yang melebihi jumlah laki-laki. ${ }^{13}$ 
Masifnya kampanye atas poligami di berbagai panggung pengajian dan melalui berbagai booklet kajian tentang Islam yang disebar di berbagai masjid menjadikan praktik pernikahan poligami bertambah marak di Indonesia. Tercatat bahwa jumlah pernikahan poligami meningkat dari 67.894 kasus menjadi 183.805 pada tahun 1999. Jumlah ini semakin meningkat pada tahun 2000 dan 2001 menjadi 145.609 untuk yang terdata dan terdaftar saja. $^{14}$

\section{Penerimaan Istri Pertama dalam Poligami}

Konstruksi menarik lain dalam film Surga yang Tak Dirindukan 1 dan 2 selain rasionalisasi poligami adalah penerimaan istri pertama terhadap praktik pernikahan poligami. Dikisahkan bahwa meskipun pada awalnya Arini merasa kecewa dan patah hati setelah mengetahui praktik poligami diam-diam yang dilakukan oleh Pras, cintanya pada sang suami dan sang putri Nadia, dan juga cintanya pada Tuhan membuatnya untuk dapat menerima keberadaan Meirose sebagai istri kedua.

Film menggambarkan bagaimana proses penerimaan Arini pada pernikahan poligami yang tidak terjadi begitu saja. Arini sempat mengalami pergulatan batin dan goncangan yang hebat. Dalam scene-scene yang penuh dengan amarah dan air mata, Arini digambarkan kehilangan akal sehatnya. Ia berteriak-teriak kalap dan mengusir Pras dari rumah tanpa mempedulikan perasaan Nadia. Tidak hanya itu saja, ia juga mendatangi kediaman Meirose dan mencaci-maki perempuan tersebut. Arini dengan emosi mengatai Meirose sebagai perempuan perebut suami orang. Arini kemudian tenggelam dalam emosi dan amarahnya sendiri. Ia menangis sejadi-jadinya hingga melalaikan tanggung-jawabnya kepada sang putri.

Sejatinya kemarahan perempuan yang dipoligami dalam film dengan baik menggambarkan goncangan emosi yang dialami oleh istri pertama yang baru mengetahui bahwa suami mereka melakukan praktik poligami. Penelitian oleh Fitriana dengan baik menggambarkan bagaimana kalut dan emosionalnya para istri yang mengetahui bahwa suami mereka melakukan praktik poligami bahkan pada suku yang dikenal memiliki rerata praktik poligami cukup tinggi seperti suku Sasak. Mendapati bahwa suami mereka melakukan praktik poligami secara diam-diam, para informan merasa gemetar, lemas, ingin ambruk, hingga pingsan. Bahkan ada yang marah-marah mendatangi rumah istri kedua sambil menghunus pisau dan mengamuk sampai menjadi tontonan orang. Informan lain ada yang 
mengalami depresi, mengunci diri selama berbulan-bulan, tidak mau makan, sering pingsan, hingga merasa ingin bunuh diri. ${ }^{15}$

Kasus terbaru tentang terbongkarnya praktik poligami yang telah dijalani bertahuntahun oleh Ustadz Al Habsyi, seorang ustadz yang populer di media nasional, sehingga mengakibatkan istri pertamanya menggugat cerai di pengadilan ${ }^{16}$ menjelaskan dengan baik tentang goncangan yang dialami oleh pihak perempuan karena praktik poligami yang dilakukan tanpa sepengetahuan istri pertama. Para istri umumnya merasa dibohongi dan merasa patah hati hingga membuat mereka hancur.

Namun demikian, terlihat jelas bagaimana film mengkonstruksi kemarahan dan perlawanan para perempuan ini sebagai sesuatu yang emosional, irasional, tidak terkendali, dan cenderung gila. Adegan Arini berteriak kalap, menangis tersedu-sedu, hingga mencacimaki Meirose menampilkan bagaimana film ingin membuat penonton untuk tidak memihak Arini. Alih-alih merasa iba, penonton akan merasa bahwa Arini adalah sosok yang terlalu mementingkan diri sendiri, tenggelam dalam emosi pribadi, hingga melupakan tanggung jawabnya sebagai seorang ibu. Pada titik ini Arini digambarkan sedang mengalami krisis spiritualitas karena marah dan berusaha melakukan perlawanan terhadap sesuatu yang diperbolehkan oleh Tuhan. Konsep klasik oleh Sandra Gilbert bahwa perempuan dalam cerita selalu diposisikan sebagai sosok yang lembut bak malaikat (angelic) atau penuh amarah bak setan (demonic) direpresentasikan dengan jelas oleh sosok Arini. ${ }^{17}$

Itulah sebabnya film tidak memberikan waktu berlama-lama bagi Arini untuk 'menyalahi' kodratnya sebagai istri yang baik dan taat. Saat sang putri Nadia meminta Pras untuk kembali pulang, Arini dengan penuh kesadaran mau membuka pintu untuk Pras. Pun ketika Pras mengalami kecelakaan yang berujung koma, Arini serta-merta membukakan pintu maaf lebar-lebar untuk Pras dan bersedia menerimanya sebagai suami. Tidak hanya itu, Arini bahkan mau menerima keberadaan Meirose sebagai istri kedua meskipun hal ini masih belum bisa diterima oleh Meirose yang merasa bersalah.

Film juga seolah menafikan begitu saja dosa Pras karena menikahi Meirose secara diam-diam. Padahal, menikahi perempuan lain secara diam-diam, menurut Komnas Perempuan, sejatinya adalah sebuah bentuk kekerasan psikis. ${ }^{18}$ Hal tersebut karena poligami yang dilakukan oleh suami secara diam-diam dapat membuat istri pertama berada pada posisi sulit untuk menerima poligami ataupun menolaknya. Bila beberapa orang memutuskan untuk 
menerima sebagaimana yang dilakukan oleh Umi Ela, Bunga, dan Yeyen ${ }^{19}$, umumnya mereka menerima karena terpaksa. Usaha keras mereka untuk bertahan ini terutama demi kepentingan putra-putri dan keutuhan keluarga. Ini tentu berkebalikan dengan Arini yang pada akhirnya dibuat untuk menerima begitu saja setelah ia merenungi perintah Tuhan dalam Al Quran dan juga karena rasa ibanya pada Pras.

Penerimaan Arini pada poligami tanpa syarat itu semakin digarisbawahi pada sekuel film tersebut yang mengisahkan bagaimana perjuangan Arini untuk membawa pulang Meirose dari pelariannya ke Budhapest. Setelah bertahun-tahun tidak bertemu Meirose Arini ingin mengajaknya kembali menjalin mahligai pernikahan poligami bersama Pras terlepas dari kondisi bahwa pada saat itu Meirose telah memiliki kehidupan yang lebih mapan di Budhapest. Ia telah menjadi perempuan yang mandiri secara finansial karena sukses menjalankan bisnis kecilnya. Tidak hanya itu saja diceritakan bahwa Meirose telah memiliki kekasih dokter tampan asal Indonesia, Dokter Syarif.

Hanya saja, dengan kentara film menggambarkan bahwa sosok tampan yang cerdas ini masih tidak sebanding dengan Pras yang tidak saja tampan dan cerdas, tetapi juga memiliki pengetahuan agama yang dalam. Ini artinya, Pras dilabeli sebagai pria yang lebih mampu membimibing Meirose ke jalan agama dibanding dokter Syarif. Dangkalnya pengetahuan agama dokter Syarif secara praktis menjadikan dirinya sebagai si lain yang derajatnya tidak sebanding dengan Pras. Pras dengan segala idealitas karakter yang melekat padanya ditahbiskan sebagai sang maskulin dominan yang menghegemoni bentuk maskulinitas lain yang tidak sesuai. ${ }^{20}$

Usaha keras Arini untuk membujuk Meirose kembali ke Indonesia dan melanjutkan rumah tangga mereka bertiga seolah menunjukkan penerimaan Arini yang tanpa syarat pada pernikahan poligami sekaligus seolah menafikan berbagai potensi konflik yang bisa timbul dari pernikahan poligami. Arini yang pada film pertama digambarkan sempat mengalami krisis spiritualitas, pada sekuel film diceritakan telah mampu berdamai dengan diri dan emosinya. Ia menerima poligami secara ikhlas. Bahkan ia berjuang untuk menyelamatkan Meirose dari laki-laki yang tidak akan dapat membimbingnya ke jalan agama.

Pada titik ini, terlihat jelas bagaimana karakter Arini yang sangat dominan dalam film seolah menjadi agen patriarki demi Pras. Arini yang notabene merupakan tokoh utama dan menjadi center of interest film seolah menafikan adanya kemungkinan lain yang lebih baik 
bagi kehidupan Meirose dan putranya Akbar. Kegigihan Arini untuk mengajak Meirose pulang menggarisbawahi bahwa poligami adalah jawaban terbaik bagi semua. Arini menganggap bahwa pernikahan poligami adalah sesuatu yang telah diatur Tuhan. Karenanya, tugasnyalah untuk menyatukan kembali Meirose dan Pras.

Konstruksi film ini sejalan dengan konstruksi ideal poligami menurut kelompok fundamentalis Islam sebagaimana dinyatakan oleh para Tablighis yang secara terbuka mendukung dan membela poligami. Menurut mereka, poligami tidak seharusnya dipandang sebagai wahana untuk memuaskan hasrat dan nafsu, tetapi sebuah praktik terhormat, bermartabat, dan dibenarkan oleh agama, apalagi bila istri kedua adalah para janda, sebatang kara, atau miskin papa, sebagaimana Meirose. ${ }^{21}$

Penolakan Arini terhadap poligami pada awalnya adalah bentuk spontanitas sikapnya sebagai pihak yang terluka. Sedangkan penerimaannya terhadap poligami terutama didasarkan pada pembacaan tekstualis para fundamentalis atau Islamis atas ayat Quran tentang poligami. Para perempuan kelompok Islamis yang bersandar pada pendekatan tekstualis atas ayat $\mathrm{Al}$ Quran lazimnya akan menerima praktik poligami. ${ }^{22}$

Bahkan tidak jarang didapati bahwa istri kelompok Islamis dengan perekonomian yang cukup baik akan mendorong suaminya untuk menambah istri. Menurut Van Wichelen, praktik poligami kelompok ini cenderung bersifat komunal sebagaimana yang dicontohkannya dalam kasus yang terjadi di salah satu kampus di Yogyakarta ketika seorang istri mendorong suaminya untuk menikahi perempuan yang lebih muda agar sang istri muda dapat membantu menjalankan roda ekonomi keluarga dan juga membereskan pekerjaan rumah tangga. Istri muda ini juga akan meningkatkan status sosial istri pertama. Hal ini, menurut Wichelen, cukup lumrah terjadi di kalangan keluarga PKS karena para perempuan PKS cenderung mau untuk dipoligami karena menganggap bahwa hal tersebut tidak menimbulkan masalah. Selain itu, para perempuan ini beranggapan bahwa dengan menerima poligami dengan ikhlas, mereka akan mendapatkan tempat terbaik di surga. ${ }^{23}$

Interpretasi tekstualis yang menjadi dasar mayoritas praktik poligami di Indonesia berseberangan dengan pandangan para feminis muslim atas teks Quran tentang poligami. mereka menginterpretasikan ayat-ayat Quran tentang poligami sebagai preferensi Islam atas pernikahan monogami. Para feminis muslim menekankan bahwa ayat Quran 4:2-3 dan 129 bukan bertitik berat pada perintah untuk memperbolehkan poligami, sebaliknya ayat tersebut 
menekankan pada wacana tentang keadilan terutama pada anak yatim dan perempuan. ${ }^{24}$. pandangan muslim feminis ini mengimbangi pandangan tekstualis konservatif yang biasanya didasarkan atas pemikiran para pria dan menganggap poligami sebagai hak para pria. ${ }^{25}$

Bahkan, seorang muslim feminis lain, Leila Ahmed menganggap poligami sebagai sebuah institusi pernikahan yang didasari oleh hak pria untuk mengikat perempuan dan membuat mereka tak berdaya dalam relasi seksual. Menurutnya, poligami bukanlah bagian dari sunnah, melainkan sebuah refleksi budaya yang bersifat misoginis terhadap para perempuan. $^{26}$

\section{Arini dan Konstruksi Wanita yang Baik}

Film juga merepresentasikan konstruksi umum tentang 'istri yang baik' dalam sosok Arini. Istri yang baik adalah istri yang mampu melaksanakan tugas rumah tangga. Ia harus berada dalam kondisi sehat untuk bisa 'melayani' suami, menyelesaikan segala urusan dalam rumah tangga dan juga melahirkan sebagaimana tertulis dalam Undang-Undang Perkawinan Indonesia tahun $1974 .{ }^{27}$ Jika istri tidak dapat memenuhi tugas-tugas tersebut, suami dinyatakan berhak untuk menikah lagi.

Konstruksi tentang istri yang baik ini juga begitu digaungkan dalam dua organisasi yang dibuat oleh pemerintah yaitu PKK (Pembinaan Kesejahteraan Keluarga) yang menjadi payung bagi para perempuan di ranah desa untuk mengadakan berbagai kegiatan seputar kewanitaan dan juga keluarga, dan Dharma Wanita yang dibuat khusus untuk para Pegawai Negeri Sipil dan istri. ${ }^{28}$

Diceritakan bahwa Arini gagal memenuhi konstruksi wanita yang baik tersebut karena sedang dalam kondisi sakit parah pada sekuel film. Hal ini seolah memberikan amunisi tambahan bagi Pras untuk melanjutkan pernikahan poligami dengan Meirose. Arini menyadari bahwa ia tidak akan mampu lagi melaksanakan tugas-tugasnya sebagai istri akibat penyakit kanker yang dideritanya. Namun demikian, hal yang membuat kita bertanya-tanya adalah alasan Arini untuk menolak diberikan kemoterapi dan pengobatan. Arini seolah sudah menyerah dengan takdirnya untuk menikmati penyakit yang dideritanya dan memilih untuk menjalani takdir ini dengan perlahan-lahan berjalan menuju kematian. Alih-alih berusaha untuk membuat dirinya sehal kembali dan menjalani pengobatan, ia malah sibuk menyiapkan pengganti dirinya bagi Pras dan Nadia. 
Arini sama sekali tidak memperhatikan dirinya sendiri sepanjang film. Perhatiannya hanya tertuju pada kepentingan Pras semata. Ia seolah meletakkan Pras di atas segalagalanya. Bahkan ia mengesampingkan kepentingan Meirose dan juga masa depan cerah Meirose di Budhapest bersama dengan Dokter Syarif. Menurut Arini, yang telah menjadi agen patriarkhi, tidak ada rumah masa depan yang lebih tepat bagi Meirose selain bersama Pras karena Pras adalah pria yang memenuhi konstruksi idealitas pria muslim. Konstruksi patriarkhi yang begitu melekat kuat membuat Arini kukuh membujuk Meirose untuk kembali pulang untuk menggantikan perannya sebagai istri dan ibu rumah tangga bagi Pras dan anakanak. Arini yang terbutakan oleh niatnya untuk menjadi "istri yang berbakti” menempatkan kepentingan Pras di atas segalanya, dalam hal ini di atas kesehatan dan perasaannya sendiri, dan bahkan juga kepentingan perempuan lain (Meirose).

Arini sebagaimana Pras menjadi sebuah representasi wanita dan pria muslim yang utopis. Mereka baik, bahkan terlalu baik untuk menjadi kenyataan. Mereka nyaris tanpa cela dan bak malaikat. Konstruksi ideal yang utopis ini menjadi berbahaya karena pada dasarnya film telah menafikan berbagai konflik yang mungkin saja timbul akibat poligami. Pada kenyataannya poligami bukanlah suatu praktik pernikahan yang minim konflik.

Bahkan bagi wanita dengan pandangan islamis sekalipun, poligami tidaklah seindah dan seideal apa yang digaungkan oleh Puspo Wardoyo bahwa 'Poligami itu indah. ${ }^{29}$ Rivalitas antar istri kerap kali muncul dalam pernikahan poligami. Bahkan pada pernikahan poligami Rasul Saw dikisahkan dalam sirah nabawiyah bahwa Aisyah kerap kali merasa cemburu pada para istri nabi lainnya. ${ }^{30}$

Sama halnya, dalam beberapa penelitian tentang praktik pernikahan poligami di Indonesia, diketahui bahwa rivalitas antar istri kerap kali menjadi sumber permasalahan dalam pernikahan. ${ }^{31}$ Keadilan atas alokasi waktu yang harus diberikan suami oleh setiap istri, rumah yang layak, pakaian, pembagian tugas rumah tangga, merawat dan mendidik anak, akses ekonomi, dan hal-hal lainnya kerap kali menjadikan praktik pernikahan poligami menjadi sangat rumit.

Hal tersebut menunjukkan fakta tersendiri bahwa perempuan secara alamiah tidak akan dapat menikmati praktik berbagi suami. Banyak hal yang akan tercerabut dari diri mereka saat menjalani pernikahan poligami karena suami dengan segala turunannya tidak lagi murni menjadi milik istri pertama. Suami yang berpoligami harus dapat membagi waktu, 
kasih sayang, perhatian, dan juga nafkah secara adil, sesuatu yang sulit dicapai oleh pria manapun. Poligami sejatinya menuntut suatu keadilan paripurna yang sungguh sulit diwujudkan. Pada kenyataannya, banyak suami yang tidak dapat memenuhi keadilan ini di lapangan dan pada akhirnya malah menimbulkan konflik di antara para istri.

Interpretasi konvensional atas ayat Quran tentang poligami menjadi senjata ampuh para pria untuk dapat mempoligami istrinya dengan sekehendak hati, sebagaimana mayoritas poligami yang terjadi tanpa sepengetahuan sang istri pertama. ${ }^{32}$. Interpretasi konvensional ini menimbulkan kesewenang-wenangan dan hegemoni pria atas perempuan kebanyakan. Liarnya interpretasi tersebut kerap kali berakibat pada posisi sulit perempuan baik untuk menerima poligami atau bercerai, dua pilihan yang sama-sama pahit dan sulit untuk dilaksanakan tidak hanya bagi si istri namun juga bagi anak-anak. Kebanyakan para perempuan yang sejatinya tidak dapat menerima poligami terpaksa harus menerima poligami karena berbagai alasan yang tidak menyenangkan bagi mereka. Para perempuan tersebut menganggap penerimaan mereka sebagai bentuk pengorbanan spiritual demi mencapai keridhoan Tuhan. ${ }^{33}$

Sayangnya film tidak merepresentasikan kepahitan yang dialami perempuan ini sebagaimana selayaknya. Perempuan dalam film 'dipaksa' menerima poligami sebagai suratan takdir yang tidak dapat terelakkan. Tidak ada jalan lain yang lebih baik selain bersikap mengalah dengan penuh keikhlasan dan menjalani kehidupan poligami dengan penuh ketaatan. Bahkan, lebih buruk lagi, karakter utama digambarkan dapat menerima poligami dengan penuh keteguhan hati dengan mengalahkan berbagai pergulatan batin dan juga kepentingan orang lain. Representasi tokoh Arini yang menerima poligami secara mentah-mentah menjadi suatu bentuk performativitas gender yang terlalu simplistis dan idealis. Representasi semacam ini terlahir dari interpretasi tekstualis yang misoginis terhadap perempuan. Konstruksi film yang melenakan membuat penerimaan Arini terhadap poligami sebagai sesuatu yang melawan arus perjuangan perempuan untuk mencapai ekualitas. Para perempuan dalam film meskipun mandiri adalah perempuan yang begitu memuja suami terlepas dari apapun kesalahan yang pernah dilakukan. Dengan kata lain, Surga Yang Tak Dirindukan merupakan sebuah film dengan karakter utama perempuan yang tidak berbicara tentang perempuan dan tidak memihak perempuan. 


\section{Kesimpulan}

Analisis semiotik terhadap struktur cerita Surga yang Tak Dirindukan memunculkan wacana rasionalisasi poligami sebagai solusi atas permasalahan sosial yang dihadapi oleh perempuan lemah dan sebatang kara seperti Meirose. Poligami dipandang sebagai sebuah praktik yang dilakukan berdasarkan sunnah Rasul saw untuk menolong para wanita yang membutuhkan pertolongan. Hal ini secara tidak langsung memposisikan Pras sama dengan Rasul yang merupakan sang Mesiah yang dapat membantu mereka yang lemah. Terdapat konstruksi maskulinitas ideal pria muslim yang dibangun oleh struktur cerita film melalui apa yang dilakukan oleh Pras dan atribut-atribut yang melekat pada dirinya tersebut. Para pria muslim ideal adalah mereka yang dapat menyeimbangkan antara keahlian duniawi dan juga kecakapan religious. Mereka bersikap lembut dan penuh kasih tidak hanya kepada istri mereka saja, tetapi juga kepada siapapun yang membutuhkan. Maskulinitas ideal pria muslim ini menjadi suatu pernyataan dominan dalam film yang menghegemoni bentuk maskulinitas lain yang hanya terfokus pada kecakapan duniawi dan kecakapan fisik tanpa dibarengi oleh kesalehan spiritual.

Di sisi lain, film juga mengkonstruksi penerimaan perempuan sebagai sebuah kerelaan yang tidak bersyarat. Para perempuan dalam film dibuat tidak sadar oleh ketundukan mereka kepada para pria sebagai sebuah sesuatu yang dilabeli dengan ketaatan dan cinta istri kepada suami. Selain itu, para perempuan tersebut juga tersubjeksi oleh interpretasi tekstualis terhadap ayat suci tentang poligami yang mereka junjung tinggi, terlepas dari fakta bahwa sejatinya ada interpretasi lain yang dihadirkan oleh para feminis muslim terhadap ayat tentang poligami. Perempuan dalam film memilih menerima poligami sebagai bentuk peningkatan spiritualitas dan keikhlasan dalam beragama dan menjalankan perintah Tuhan. Mereka melakukan pengorbanan demi mencari keridhoan Tuhan dan mendapatkan tempat tertinggi di surga, meskipun tanpa sadar mereka telah melakukan masokisme terhadap diri mereka sendiri. Perempuan ini berbicara atas nama laki-laki dan bertindak atas nama laki-laki yang merasionalisasikan hasrat mereka atas nama perintah Tuhan dalam ayat suci. Dengan kata lain, meskipun Surga yang tak Dirindukan bergulir dari sudut pandang perempuan, film ini sejatinya tidak berbicara tentang perempuan. Arini adalah representasi perempuan yang menjadi agen patriarki dan konsep poligami yang terdapat dalam film ini bersifat misoginis. 


\section{Endnote}

${ }^{1}$ Izharuddin, Alicia. 2017. Gender and Islam in Indonesian Cinema. Palgrave Macmillan, Singapore.

2 ibid

${ }^{3}$ ibid

${ }^{4}$ Heryanto, Ariel. 2011. The Politics of Indonesian Screen Culture. NUS Press, Singapore.

${ }^{5}$ Brenner, Neil. 1999. Globalisation as Reterritorialisation: The Re-scaling of Urban Governance in the

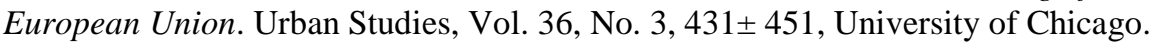

${ }^{6}$ Izharuddin, Alicia. 2017. Gender and Islam in Indonesian Cinema. Palgrave Macmillan, Singapore.

7 ibid

${ }^{8}$ Kurnia, Novi. Berbagi Suami (Love for Share): The Discourse of Polygamy in a Recent Indonesian Film.

Intersections: Gender and Sexuality in Asia and the Pacific Issue 19, February 2009

${ }^{9}$ Online: http://showbiz.liputan6.com/read/2461647/surga-yang-tak-dirindukan-film-box-office-terbaik-diiboma (diakses Maret 15 2017).

${ }^{10}$ Rohman, Arif. 2013 Reinterpret Polygami in Islam: A Case Study in Indonesia, International Journal of Humanities and Social Science Invention.

${ }^{11}$ Syaikh Abdul Aziz bin Abdullah bin Baz. Online: https://almanhaj.or.id/731-poligami-itu-sunnah-dan-tafsirayat-poligami.html (akses Februari 20, 2017).

${ }^{12}$ Rohman, Arif. 2013 Reinterpret Polygami in Islam: A Case Study in Indonesia, International Journal of Humanities and Social Science Invention.

${ }^{13}$ Johnson, Heather. 2005. There are Worse Things Than Being Alone: Polygamy in Islam, Past, Present, and Future. William \& Mary Journal of Women and the Law Volume 11, Issue 3 Article 11.

${ }^{14}$ Van Wichelen, S. 2009. Polygamy Talk and the Politics of Feminism: Contestations over Masculinity in a New Muslim Indonesia. Journal of International Women's Studies, 11(1): 173-187.

${ }^{15}$ Herlina, Fitriana. 2014. Konsep Cinta Istri Pertama yang Dipoligami: Studi Kasus pada Suku Sasak Nusa Tenggara Barat. Skripsi, Fakultas Ilmu Sosial dan Humaniora.

${ }^{16}$ Online: https://hot.detik.com/celeb/3446672/ustad-al-habsyi-poligami-bertahun-tahun-tanpa-sepengetahuanputri-aisyah (diakses Februari 27, 2017).

${ }^{17}$ Sandra M. Gilbert \& Susan Gubar. 1979. The Madwoman in The Atti: The Woman Writer and The Nineteenth Century Literary Imagination. Yale University Press.

${ }^{18}$ Online: https://news.detik.com/berita/d-3455070/komnas-perempuan-poligami-diam-diam-itu-kekerasan (diakses Maret 10, 2017).

${ }^{19}$ Herlina, Fitriana. 2014. Konsep Cinta Istri Pertama yang Dipoligami: Studi Kasus pada Suku Sasak Nusa Tenggara Barat. Skripsi, Fakultas Ilmu Sosial dan Humaniora.

${ }^{20}$ Connell, R. W. Hegemonic Masculinity: Rethinking The Concept. Gender \&Society, Vol. 19 No. 6, December 2005 829-859. University of Sydney Australia.

${ }^{21}$ Mawardi, 'Istri Nolak Poligami (Wives Reject Polygamy)', Pustaka Mawar, revised 2012, http://pustakamawar.ordpress.com/2007/11/22/istri-nolak-poligami., accessed 5 October 2012.

${ }^{22}$ Nurmila, N. 2007. Negotiating polygamy in Indonesia: between Muslim discourse and women's lived experiences. PhD thesis, Gender Studies, Faculty of Arts, University of Melbourne.

${ }^{23}$ Van Wichelen, S. 2009. Polygamy Talk and the Politics of Feminism: Contestations over Masculinity in a New Muslim Indonesia, Journal of International Women's Studies, 11(1): 173-187.

${ }^{24}$ Wadud, Amina. 1999. Qur'an and Woman: Rereading a Sacred Text from Women's Perspective. Oxford University Press: New York, Oxford.

${ }^{25}$ Van Wichelen, S. 2009, 'Polygamy Talk and the Politics of Feminism: Contestations over Masculinity in a New Muslim Indonesia', Journal of International Women's Studies, 11(1): 173-187.

${ }^{26}$ Nurmila, N. 2007. Negotiating polygamy in Indonesia: between Muslim discourse and women's lived experiences. PhD thesis, Gender Studies, Faculty of Arts, University of Melbourne.

${ }^{27}$ Undang-undang Republik Indonesia Nomor 1 Tahun 1974 Tentang Perkawinan

${ }^{28}$ Van Wichelen, S. 2009, Polygamy Talk and the Politics of Feminism: Contestations over Masculinity in a

New Muslim Indonesia, Journal of International Women's Studies, 11(1): 173-187.

29 ibid

${ }^{30}$ Online: https://media.ihram.asia/2016/09/17/kisah-cemburu-aisyah-terhadap-istri/ (diakses Maret 3 2017). 
${ }^{31}$ Nurmila, N. 2007. Negotiating polygamy in Indonesia: between Muslim discourse and women's lived experiences. PhD thesis, Gender Studies, Faculty of Arts, University of Melbourne.

32 ibid

${ }^{33}$ Online. Pain \& Growth, in Coping with Polygamy: A First Wife's Jihad, at

httpJ/www.polygamyfirstwife.com/pg.htm (diakses Maret 2017).

\section{Daftar Pustaka}

Brenner, Neil. 1999. Globalisation as Reterritorialisation: The Re-scaling of Urban

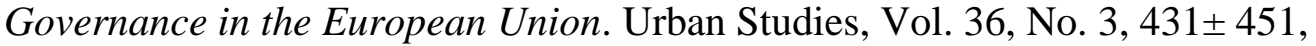
University of Chicago.

Connell, R. W. Hegemonic Masculinity: Rethinking The Concept. Gender \&Society, Vol. 19 No. 6, December 2005 829-859. University of Sydney Australia.

Daniels, P. Timothy. 2013. Performance, Popular Culture, and Piety in Muslim Southeast Asia. Palgrave Macmilan.

Heryanto, Ariel. 2011. The Politics of Indonesian Screen Culture. NUS Press, Singapore. Izharuddin, Alicia. 2017. Gender and Islam in Indonesian Cinema. Palgrave Macmillan, Singapore.

Johnson, Heather. 2005. There are Worse Things Than Being Alone: Polygamy in Islam, Past, Present, and Future. William \& Mary Journal of Women and the Law Volume 11, Issue 3 Article 11.

Kurnia, Novi. Berbagi Suami (Love for Share): The Discourse of Polygamy in a Recent Indonesian Film. Intersections: Gender and Sexuality in Asia and the Pacific Issue 19, February 2009.

Mawardi, 'Istri Nolak Poligami (Wives Reject Polygamy)', Pustaka Mawar, revised 2012, http://pustakamawar.ordpress.com/2007/11/22/istri-nolak-poligami., accessed 5 October 2012.

Nurmila, N. 2007. Negotiating polygamy in Indonesia: between Muslim discourse and women's lived experiences. PhD thesis, Gender Studies, Faculty of Arts, University of Melbourne.

Rohman, Arif. 2013 Reinterpret Polygami in Islam: A Case Study in Indonesia, International Journal of Humanities and Social Science Invention.

Sandra M. Gilbert \& Susan Gubar. 1979. The Madwoman in The Atti: The Woman Writer and The Nineteenth Century Literary Imagination. Yale University Press.

Undang-undang Republik Indonesia Nomor 1 Tahun 1974 Tentang Perkawinan

Van Wichelen, S. 2009. Polygamy Talk and the Politics of Feminism: Contestations over Masculinity in a New Muslim Indonesia, Journal of International Women's Studies, 11(1): 173-187.

Wadud, Amina. 1999. Qur'an and Woman: Rereading a Sacred Text from Women's Perspective. Oxford University Press: New York, Oxford.

Online:

Online: http://showbiz.liputan6.com/read/2461647/surga-yang-tak-dirindukan-film-boxoffice-terbaik-di-iboma (diakses Maret 15 2017).

Online: https://news.detik.com/berita/d-3455070/komnas-perempuan-poligami-diam-diamitu-kekerasan (diakses Maret 10, 2017).

Online: https://hot.detik.com/celeb/3446672/ustad-al-habsyi-poligami-bertahun-tahun-tanpasepengetahuan-putri-aisyah (diakses Februari 27, 2017).

Online. Pain \& Growth, in Coping with Polygamy: A First Wife's Jihad, at httpJ/www.polygamyfirstwife.com/pg.htm (diakses Maret 2017).

Online: https://media.ihram.asia/2016/09/17/kisah-cemburu-aisyah-terhadap-istri// (diakses Maret 3 2017). 
